IBAD, 2019; (Özel Sayı): 486-496

\title{
Sanat Yapıtı Bellek İlişkisi
}

\section{Dr. Öğr. Üyesi Abdül Tekin}

Geliş tarihi: 06.09.2019

Kabul tarihi: 27.09.2019

\section{Atıf bilgisi:}

IBAD Sosyal Bilimler Dergisi

Sayı: Özel Sayı $\quad$ Sayfa: $486-496$

Yıl: 2019

This article was checked by inthial.net. Similarity Index 9\%.

\section{$1 \quad$ Iğdır Üniversitesi, Türkiye} abdultekin@gmail.com

ORCID ID 0000-0001-5392-562X

* Sorumlu yazar

\section{ÖZ}

Post Prodüksiyon terimi Nicolas Bourriaud tarafindan sanatta yapıtın icrası sonrasın ifade eden ve sinema- televizyon dünyasının yaygın olarak kullandığı bir terimdir. $\mathrm{Bu}$ terim Bourriaud penceresinden sanatla ilişkilendirilirken daha çok yapıtın üretimi sonrasında meydana gelen etkiler üzerinden düşünmeyi önermektedir. $\mathrm{Bu}$ tarif açıkça zamanın sanat eserinde üretim sonrasını daha önemli kılan bir yaklașımı sunmaktadır. Zaman burada yalnızca değiştiren, dönüştüren yanı ile değil aynı zamanda yapıtı üreten kişinin kontrolü dışında gelişen bir etken olarak da önemli olduğu gözlenmektedir. Toplumsal anlamda yapıldığı zamanın ötesine geçen sanat eserlerinin bu bağlamda ulaşılan her bellekte farklı anlamlarla ilişkilendirilmesi önemsenmektedir. Zamanın yapıtın gerçek değerine ulaşmada önemli bir unsur olduğu gözlenir. Geleneksel müze ve galeri sisteminin eleştirisinde sıklıkla dile getirilen müzelerin ve galerilerin zamanın dönemsel özelliklerini yansıtmada yeterince uygun olmaması bu durumu destekler. Hatta dönüşen zamanın yapıtın anlamlandırılmasındaki etkilerinin tam anlamıla ifadesinde de zamanın galeri ve müzelerde yeterince temsil edilemediği dahi iddia edilebilir. Aynı zamanda bu tür mekanların benzer zamanlarda yapılan eserleri bir araya getirerek eseri sunma yöntemi de üzerine düşünülmesi gereken bir durumdur. Bu durum dönüșen zamanın etkilerini yeterince anlaşılabilmesinde önem taşımaktadır. Zamanın bütün bu etkileri değerlendirildiğinde post-prodüksiyon tanımının da hatırlattı̆ğ bellek zaman ilişkisi zamanın sanata etkileri hesaba katıldığında daha da önemli olmaktadır.

Anahtar Kelimeler: Zaman, Bellek, Sanat Yapitı. 


\title{
Relationship between Artworks and Memory
}

\author{
Assist. Prof. Dr. Abdül Tekin
}

First received: 06.09.2019

Accepted: 27.06.2019

\section{Citation:}

IBAD Journal of Social Sciences

Issue: Special Issue Pages: 486-496

Year: 2019

This article was checked by intihal.net. Similarity Index $9 \%$.

\footnotetext{
1 Iğdır Universitiy, abdultekin@gmail.com, ORCID ID 0000-0001-5392-562X
}

* Corresponding Author

\begin{abstract}
Post production is a term widely used by the cinema and television world by Nicolas Bourriaud, who expresses after the performance of the work in art. This term is associated with art from the Bourriaud window, and suggests to think more about the effects that occur after the production of the work. This description clearly presents an approach that makes it more important to post-production in the art work of the time. Time is observed to be important not only in changing, transforming, but also as a developing factor outside the control of the person producing the artifact. In this context, it is important to relate the works of art to different meanings in every memory that is reached. It is observed that time is an important element in reaching the true value of the work. It supports the fact that museums and galleries, often expressed in criticism of the traditional museum and gallery system, are not suitable enough to reflect the periodic characteristics of time. In fact, it can be claimed that the time cannot be sufficiently represented in galleries and museums in the literal expression of its effects on the meaning of the work. At the same time, it is also important to consider the method of presenting works by combining the works of such spaces in similar times. This situation is important enough to understand the effects of the transformed time. When all these effects of time are evaluated, the memory-time relation which the post-production definition reminds is even more important when it is taken into account the effects of time on the art.
\end{abstract}

Keywords: Time, Memory and Art Product. 


\section{GİRIŞ}

2019 sonbaharında İstanbul'da yapılması beklenen Uluslararası İstanbul Bienali'ne küratör olması için sanat dünyasında önemli etkiler yapmış bir isim olan Nicolas Bourriaud getirildi. Özellikle "İlişskisel Estetik" isimli eseri ile adından söz ettiren küratörün sanat yapıtında ikili algılamanın önemine vurgu yaptığı değerlendirmeleri son derece önemlidir. Post prodüksiyon tanımı ile düşünürün belleğe yönelik bir ilişki türünü gündeme taşıdığı gözlenmektedir. Bellek yalnızca hatırda kalan unutulmayana ya da bir kavramla ilişkili bir temsili değil, kişiler arasındaki hali ile sanatçının pek de öngöremediği bir çizgide, yapıtın anlamlanmasında da önem taşıyan ilişkiyi işaret etmektedir.

\section{Sanat Yapıtının Üretimi Sonrasını Düşünmek}

Neoliberal politikaların sanat ve toplumsal ilişkileri üzerine etkilerinin önemli ölçüde hissedildiği 1990'larda; yaptığı çıkışı sonrası Nicolas Bourriaud, “ilişkisel Estetik”te toplumsal ilişkiler temelinde, sanat eserinin dönüşümü hakkında önemli tespitler ortaya koymuştur. Bu tespitlerden bir tanesi de özellikle sanat nesnesinin ürettiği estetik değerin tüketim ilişkileri içinden yarattığı etkidir. İlişkisel Estetik'te Nicolas Bourriaud, modernizmin ilerleme sürecinde sanatın öncü rolünün değişerek olas1 evrenler üzerinden ilişkiler temelinde yeniden kurgulandığını belirtir.

$\mathrm{Bu}$ olası evrenlerde çağdaş sanatın zamanın tartışmaları etrafında kendini yeniden defalarca kurguladığı görülür. $\mathrm{Bu}$ tartışmaların içinde özellikle sanata atfedilen değerde Karl Marks'ın "Toplumsal Aralık" tanımlamasını mesnet alır. Sanatın, toplumsal-ekonomik yaşamdan azade kendi arzu ve önemini yaratarak ürettiği gerçekliği ile yer araması kendi varlığının meşruiyeti ile toplumsal alanda varlığına ilişkin farklı bir yol izler. Mehmet Doğan ilişki ve toplumsallık üzerine Marksçı felsefe temelinden hareketle yaşam şartlarının iyileştirilmesi penceresinden konuya yaklaşır. Bu iyileştirme salt ekonomik değil aksine sosyal ilişkilerin geliştirilmesine yöneliktir. Bu açıdan insani yaşam şartlarının günden güne iyileştirilmesi penceresinden estetiğin ilişkisel yaklaşımının temellerini oluşturur (Doğan, 1975, s. 118). Sanatçı kendi üretimi ile ortaya koyduğu bu türlü bir ilişkiyi toplumsal ilişkiler ağı içinde önemsemelidir.

Sanatın toplumsal varlık katmanları içinde yeniden değer kazandığı bu süreçte ilişkilerin önemi üzerinden yeni bir bellek arayışına girdiği gözlenir. Bourriaud tarih üzerinden yaptığı değerlendirmede değişen toplumsal roller üzerinden insani ilişkileri çözümlemektedir. Buna yönelik ise uygulamanın daha fazla oranda insan ilişkilerine odaklandığını 1990'lardan başlayarak ilişkilerin etrafında gelişen sanatsal uygulamaların önemsendiğini gözlenmektedir. Bu noktada özellikle sanatçının işini üretimi sonrasını değerlendiren işler üzerine odaklanıldığını belirtmektedir. Üretilen işler sanatçıların kurgulamadığı yönde toplumsallık fikirlerinin modelleri üzerinden oluşturulmaktadır (Bourriaud, 2005, s. 46).

Çağdaş zamanlardaki izleyicinin etkisine yönelik Başak Şenova, izleyicinin daha aktif olması gerektiğini belirtirken, izleyicinin beraberinde getirdiği geçmiş deneyimlerini, bilgi ve birikimlerini hayatta edindiği deneyimleri ile aktif olması gerektiğini belirtmektedir. Bu durum ise izleyicinin pasif algılanışının değişimine yol açmasına vurgu yapar (Çalıkoğlu, 2005, s.15). Özellikle ilişkisel sanatın 1960'ların başında ortaya çıkan kavramsal sanat ile bağlantılı olduğu yönünde bazı değerlendirmeler yapılmıştır. Ancak kavramsal sanatın dışında ilişki sanatı denen şeyin bugünkü koşullar üzerinden sanatsal eylemlerin yarattığı sosyallikler çerçevesinden çözümlenmesi olarak görmek olasıdır. Burada muhtemel gelecek beklentilerine bağlanmadan şimdiki zamanın getirilerine odaklanmak gereklidir. Sanatın ütopyalar kurgularken aynı zamanda da anın gerçeklerine yoğunlaşması önemlidir. Kavramsal sanat gibi Process Art (süreç sanatı) da Bourriaud'a göre nesnenin ya da sürecin ele alma biçimiyle birbirine benzer sonuçlar doğurabilecektir. Ancak ilişki sanatındaki fark, asıl hedeflenen sonucun mental çıktıları ile değil ürettiği ilişkilerin bellekle yeniden kurgulanabilme gücüdür. $\mathrm{Bu}$ kapsamda Jens Haaning'in gerçekleştirdiği "Türkçe fikralar 1994" çalışması örnek olarak verilebilir. (Resim 1). 


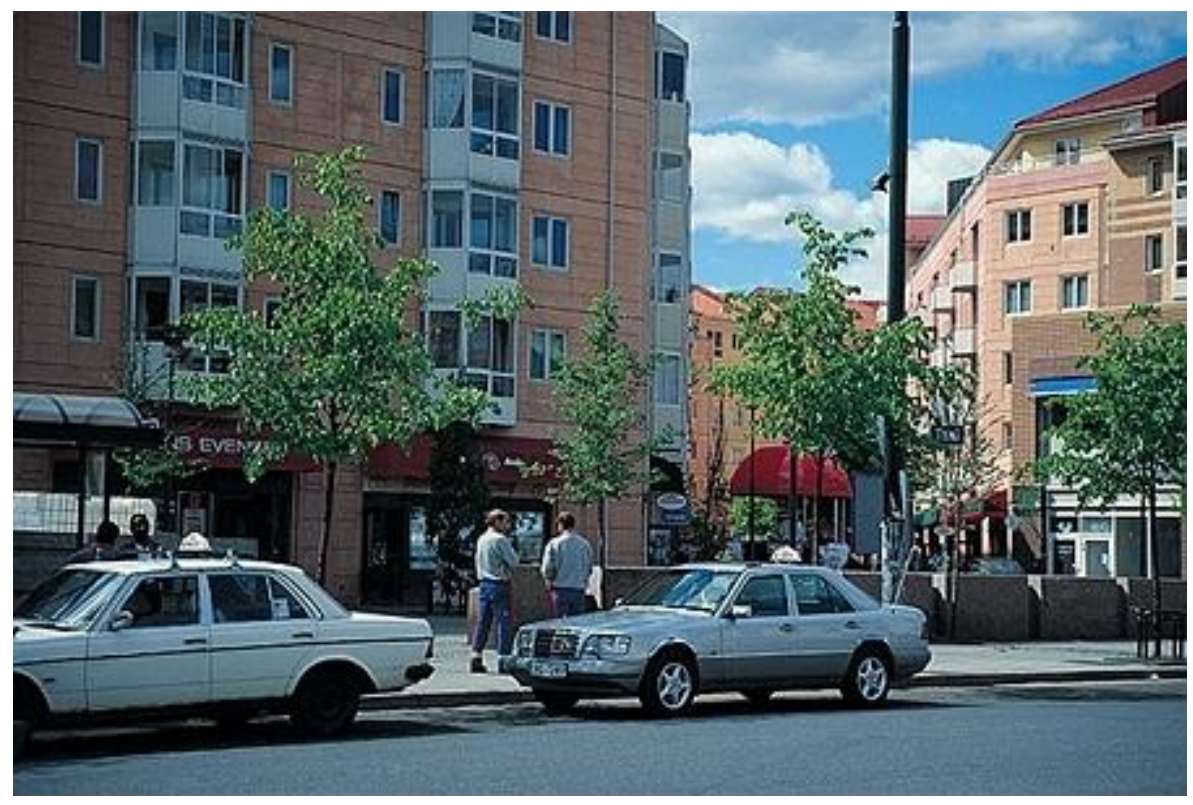

Resim 1. Jens Haaning “Turkish Jokes” 1994 Atina Bieanali

Haaning meydanda gerçekleştirdiği çalışmasında hoparlör ile Türkçe fikralar anlatmıştır. Etkinliğe katılanlardan gülenlerin yalnızca göçmenler olması sanatın anlık topluluk oluşturma gücünü ve seçkinci birleştiriciliğinin ince bir eleştirisi olarak sunulmuştu. Bu türlü bir iletişim ve algılama ile yapıt sadece ona bakanların algılarında tekrar üretilmeye devam eder. Bu ilişkinin üretilmesinde kolektif belleğin birlikteliği ile olası sonuçlarını belirlemede önemlidir.

Geleneksel sanat pratiklerinde yer alan izleyici ve yapıt ilişkisini belirli bir kolektivite ile bakmaktaydılar. Bu birliktelik toplumsal birlikteliğin sanatla yeni bir algılamada doğuracağı ilişkiler ile oluşacak bellek ile ilişkili görülmekteydi. Buna yönelik Beth Hinderliter, William Kaizen, Vered Maimon, Jaleh Mansoor ve Seth McCormick "Bireysel deneyime dayanan geleneksel izleme biçimlerinin anlamını kaybettiğinin anlaşılması, kolektivite meselesini öncelikli bir gündem haline getirmiştir" sözleri önemini ortaya koyar (Hinderliter, Kaizen, Maimon, Mansoor \& McCormick, 2018). Fakat bu noktada öne çıkan en önemli eleştirilerden bir tanesi de kolektif belleğin tanımlanmasında yer alan ortaklık ya da bir amaca yönelim konusudur. Belleğin beklentiler dahilinde şekillenmesinde üretilen içerikle birlikteliğinin doğuracağı sonuçlar önceden hesaplanabilir olarak görülmekteydi.

Bu beklentiye yönelik M. Reşat Başar ise izleyicinin doğuracağı ilişkinin hesabına yönelik değişimi ön plana çıkarır. Başar, sanat yapıtının doğru biçimde çözümlenebilmesi için izleyicinin rolüne vurgu yapar (Başar, 2015, s. 104). Belleğin üretim sürecindeki öneminden hareketle yaşayan aklın dönüşümüne yönelik önemli adımlar seyircinin oluşturduğu bağlar üzerinden kurgulanan işler üretilmektedir. Son dönemde artan bu ilginin tesadüfi gelişiminin yapıtın üretimi sonrasında yapacağı katkı Bourriaud tarafindan, "Dolayısıyla sanatçılarla ürünleri arasındaki ilişkiler, öteki ile ilişkinin barındırdığı çeşitli olasılıklar ya da katılımc1 sanatsal projeler giderek artıyor. Seyirciler gitgide daha çok hesaba katılıyorlar. Sanki artık, 'bir uzak'ın biricik ortaya çıkışı' olan sanatsal aurayı seyirci yaratıyor" sözleri ile belirtilmektedir (Bourriaud, 2005, s. 98). İlişkiler temelinde ele alınan konunun nesnelliği ile ilgili gerçeklik tartışmaları dikkat çekicidir. Bourriaud gerçekliğin ele alınışının konudan uzak bir kişi ile ele alınabilecek bir parametre olduğunun altını çizmektedir. Bu doğrultuda da nesnel algılamanın sınırlarını gerçekliğin tanımı ile belirler (Bourriaud, 2005, s. 130). Sanatsal göstermenin sunduğu gerçekliği de bu kapsamda ele alınabilir ve bu belirtilen gerçeklik tesadüflerden öte bir yapıdadır. Yani sunulan gerçeklik sanatta tesadüf olarak bile algılansa da tesadüfi değildir. Örneğin Duchamp ready made (hazır nesne) bir malzemeyi kendi oluşumu dışında ele alarak izleyicinin katkısını sanatın ele alınışında sözsel bir düzeye indirgeyerek gerçeklik bağlamında sanatçının rolünü yeniden tanımlamışır. Resim 2'de bu kurgulama gösterilmektedir. 


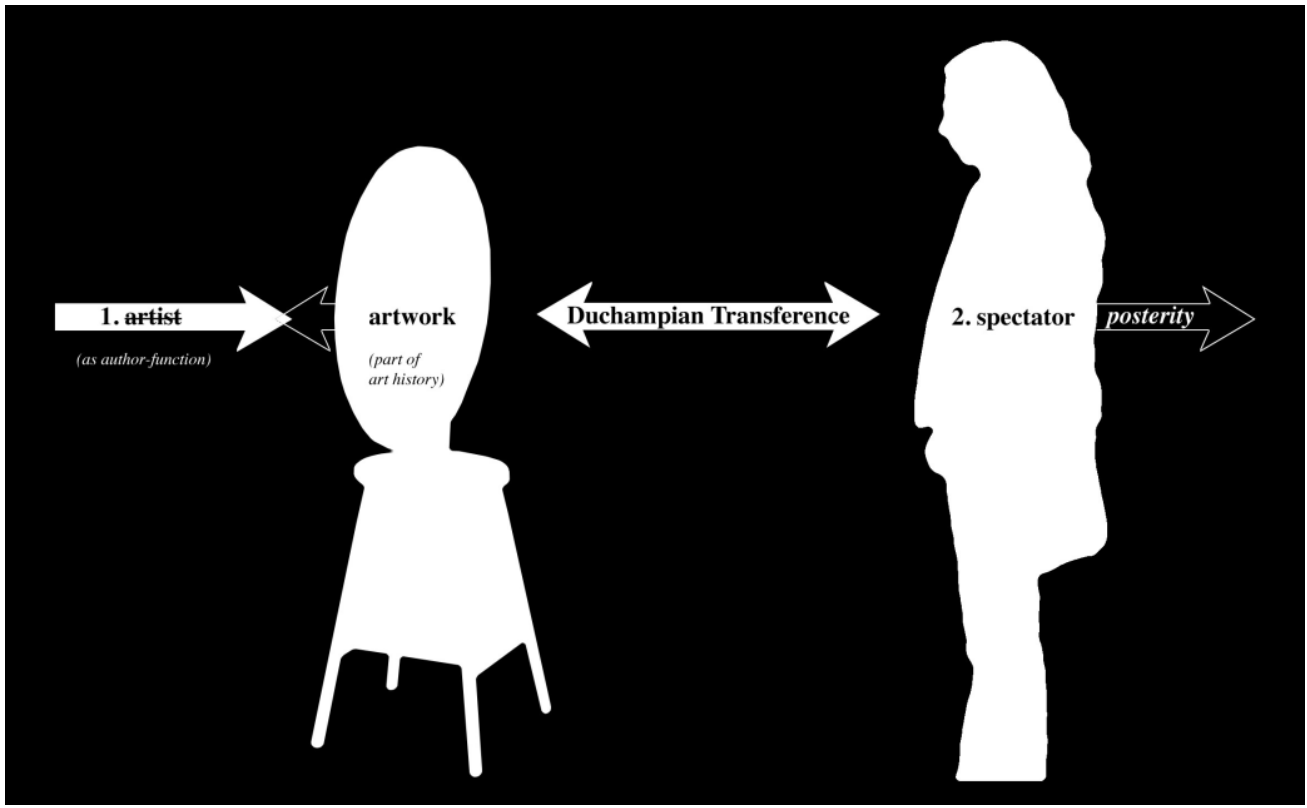

Resim 2. Marcel Duchamp’ın ilişkisel boyutta seyirci ile teması.

İzleyiciye yönelik sanatsal etkide sanatçının rolünü toplumdan uzak düşünmek ve belleklerdeki karşılığını hesaba katılması sanatı toplumdan izole bir yapıya sürükler. Özellikle çağdaş sanatın önemli isimlerinden olan pek çok isimde bu durum eleştirilerek sanatçının uzakta bir zirvede oluşu sıklıkla eleştirilmiş̧ir. Ayrıca sanaţ̧ının bellek ile olan ilişkisinin yapııın anlamlandırılmasındaki katkısına yönelik Bourriaud, "Guttari'nin postutları, Marcel Duchamp'ın 1954 yılında verdiği ünlü Houston Konferans'ında 'yaratıcı süreç' hakkında ortaya koyduğu postutlara çok yakındır. Bakan kişi yapıtın eşyaratıcısıdır, çünkü" (sanatçının) gerçekleştirdiği şey arasındaki fark" demek olan "sanatçı katsayısı" üzerinden yaratının gizine girer" der. (Bourriaud, 2005, s. 160). Bu noktada Bourriaud insan yaşamında tüketim ve mal endüstrisi üzerinden yapılan müdahalenin yalnızca kendi kaderi üzerinden kurgulanmadığını, aksine insan yaşamlarının, gösteri üzerinden, bu kadere yön vermenin esas olduğu bir düzeni önemsediğini aktarır.

Özellikle Guy Debord'nun tarifi üzerine söylediği insanlar arası etkileşimin dolayımlı yaşanmasının altını çizerken, bu etkileşimlerin yerini temsillere bıraktığının altını çizmektedir. Buradan yola çıkarak da insanlar arası ilişkilerin kenara bırakıldığı tarihi bir sıralamanın bu ilişkilerin özüne bakmadan oluşturulamayacağını belirtmektedir. Özellikle de sanat ve toplumsal süreçlerin tüketim kültürü ve iktisadi anlamda toplumun sanatla beslenmesinde, kesin anlamda yıkıcı bir karşı duruş sergilediğine yönelik önemli bazı değerlendirmeler yapılmaktadır. Özellikle üretim sonrası planlanan dönüşümlerin belirleyicisi olarak yalnızca sanatçı ve yapıtını önemsemek, günümüz koşullarında pek olası değildir.

"Gösteri kendini, hem bizzat toplum olarak, hem toplumun bir parçası olarak ve hem de bir birleştirme aracı olarak sunar. Gösteri, toplumun bir parçası olarak, özellikle, bütün bakış ve bilinçleri bir araya getiren sektördür. Bu sektör ayrı olduğundan, aldatılmış bakışın ve yanlış bilincin yeridir ve gerçekleştirdiği birleşme genelleştirilmiş ayrılığın resmi dilinden başka bir şey değildir" (Debord, 1996, s. 14).

Debord'nun sanatın tarihsel konumlanmasında etken bir söylev olarak önem kazanan sanat hamilerinin toplumu düzenlemedeki önemi üzerinden değerlendirmektedir. Sanatsal belleğin tanımlamasına bu kapsamdan bakarken özellikle çağdaş tanımında geçen zamanötesiliğin anlamının önemsendiği gözlenir. Sanatın bellek ile ilişkisinin değerlendirilmesinde zaman önemli bir unsurdur. John Rajchman, "Başta Fransız felsefesi olmak üzere Avrupa felsefesinde kilit bir soruyu ayırt etmek mümkün; Agamben “çağdaş”'n Foucault'nun l'actuel dediği şeyle aynı anlama geldiğini öne sürüyor. Tabii Foucault da bu fikri, kısmen, 19. yüzyıl ortalarında Alman tarihselciliğinin hastalıklarına bir nebze diriltici unutkanlık zerk etmek isteyen Nieztsche'nin zamana aykırı vakitsiz (l'intempesstif) kavramından devşirmiştir" 
diyerek kökenini açıklamaktadır (Rajchman, 2013, s. 21). Bellek oluşumunda, özellikle toplumsal hafızanın mekanları olarak, sanatın yalnızca sunulduğu mekanlar olarak müzelerin de zamanı dondurarak sürekliliği ile soyutlanmış bir zaman dilimi içinde var olur.

\section{Sanatta Postprodüksiyon Uygulamaları ve Bellek İliş̧kileri}

Sanatta yapıtın üretimi sonrasını bir yeniden üretim olarak değerlendiren Bourriaud'nun ortaya koyduğu sosyal ağların ürettiği veriler mevcut bellek oluşumu adına önemli veriler sunmuştur. Sanatın üretimi sonrasını hesaba katan bir yapıtın, değişmeye ve ihtimallerle genişleyen belleğin yeniden üretime katkısı yadsınamaz. İlişkiler arası beliren ihtimaller ile yeniden kurgulanan bir sanat anlayışının günümüzde yeniden üretildiği anda çoğaltılan, değiştirilen, montajlanan üretim sürecinin devamlılığı ile kurgulanan bir yöne doğru uzadığı gözlenir.

"Nasıl ki, Duchamp sosyal olanı, kapitalist üretim biçiminin özgülüğü içinde, olanın gelişini sanat alanına taşıdıysa, bugün de sanat kendisini üretimin sosyal alanına doğru taşımaktadır. Nasıl sosyal olan (ready-made pisuar) sanat esiri haline geldiyse, 20. yüzyılın başında; bugün de sanat olan kapitalist emek toplumuna doğru eğilmektedir. Dökümanter sanat, sanat tarihi göndermeleri ile, sosyal alana doğru açılmaktadır” (Akay, 2004, s. 12).

Nermin Saybaşlı ise Post Prodüksiyon ile sanatın bitmemiş olan devam eden yanına vurgu yapmaktadır. Bourriaud'un Paris'te yöneticiliğini sürdürdügü Palais De Tokyo'da mekânı kurgularken sanatçının mekana müdahalesi sonrasında yeniden kullanılabilen yapısına ilişkin üretim sürecinin devam ettirildiğini aktarır. Saybaşlı seyircinin pasif konumunun değişerek sanatı anlamlandırmada okuyucu, dinleyici ve toplumdaki temsil ettiği kimliği ile katıldığının altını çizmektedir. Sanatın yaşayan belleklerdeki yeniden imaline ilişkin sosyal hayata katılımını ortaya koyar (Saybaşlı, 2004, s. 19).
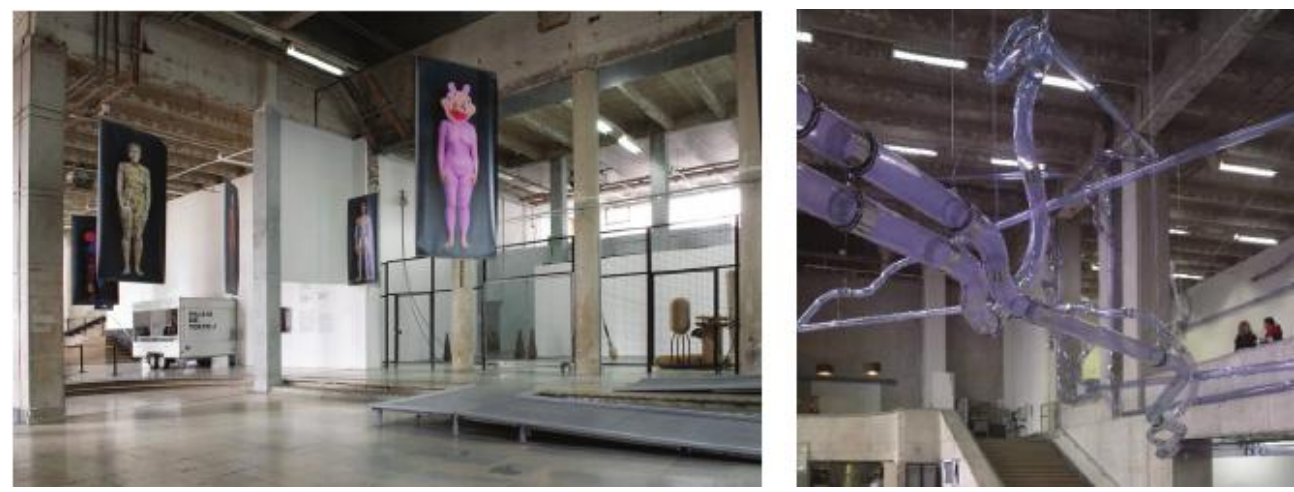

Resim 3. Palais De Tokyo Nicolas Bourriaud tarafindan yönetilen sanat mekanı.

Post-prodüksiyon tanımı ile İlişkisel Estetik'te ortaya koymuş olduğu fikirleri geliştiren Bourriaud, bellek ve sanat ilişkisinde önemli tespitler yapar. Bourriaud, İlişkisel Estetik’ten sonra postprodüksiyon ile kolektif bir yaratımın bellek ile birlikteliğinin önemini ortaya koymuştur. Ayrıca postprodüksiyon ile internetin ortaya çıkışı sonra bilginin yapılandırılmasına odaklanırken, ilişkisel estetik tanımlamasında ise bu ilişkilerin yarattığı deneyimlerin yol açtığı şenlikli ve etkileşimli havayı yansıttığını belirmektedir (Bourriaud, 2004, s. 23).

Özellikle tüketim ve üretim arasındaki var olan sınırların kaybolmaya başlaması kullanım kültürü veya etkinlik kültürü olarak tanımlanan yeniden yorumlanan bir başlama işareti olarak alınmıştır. Mevcut olan içerik ve bağlamın yeniden üretme değil, hali hazırda olanları farklı ihtimaller ile varlık alanlarına yeniden dahil etme söz konusudur. Dikkatlerden kaçırılmaması gereken şey eseri üretmek kadar sonrasını düşünmektir.

Sanatsal alanda yeniden kurulma ve kurgusallık Sitüasyonisyler'ce günlük hayatın dönüşümüne yönelik adımlar açısından ele alınan bir imal şekliydi. Bu yapının işleyişine yönelik Bourriaud, Guy Debord, Asger Jorn ve Gill Wolman'la başlayan ve kentler, binalar ve sanat işleri arka fonun bir parçası ya da karnaval ve oyuncul araçlar olarak düşünüldüğünü aktarır. Bu tarihsel arka plan ile Situationistler la 
D'erive'i ile sanki film setleriymiş gibi çeşitli kentsel sahneler yoluyla yol bulma tekniğini ürettikleri görülür. Temelinde ise önemsenenin deneyimlemeye dayalı pratikler olarak göze çarpmaktadır. Üretilen sanatsal içeriğin kısa ömürlü oluşu ve maddesellikten yoksunluğu, belirlenmiş herhangi bir sınırlandırmaya dirençli ve akıp geçen zamanın sanatı olarak tanımlanması dikkat çekicidir (Bourriaud, 2004, s. 59).

1960'larda artan aşırı endüstriyel üretim eğiliminin sonucu olarak dünya genelinde ihtiyaç fazlası malların arttığı gözlenir. Bourriaud bu durumu sanatla ilişkilendirirken, üretimin kaotik bir biçimde hızla çoğalmasının, kavramsal sanatçıları çalışmalarını soyutlaştırmaya yönlendirirken, post-prodüksiyon sanatçılarını ürünleri karıştırma ve bir araya getirme stratejilerine yönlendirdiğini belirtir. Aşırı üretim artık bir problem olarak değil, doğanın kendini yeniden üretmesinin bir yolu olarak görülmektedir. Bourriaud Postprodüksiyon isimli eserinde çağdaş sanatçı Rirkrit Tiravanija'nın üretim pratiğinden yer yer bahseder. Tiravanija, sanatsal pratiğinde sinema yönetmeni gibi ele aldığı gösterimleri ile oyucuları doğaçlama konusunda özgür bırakmıştır. Kendiliğinden gelişen bu rastlantısal belleğin sanattaki üretim sonrasını bir yeniden imal etme uygulaması olarak toplumsallık önemsenmektedir.

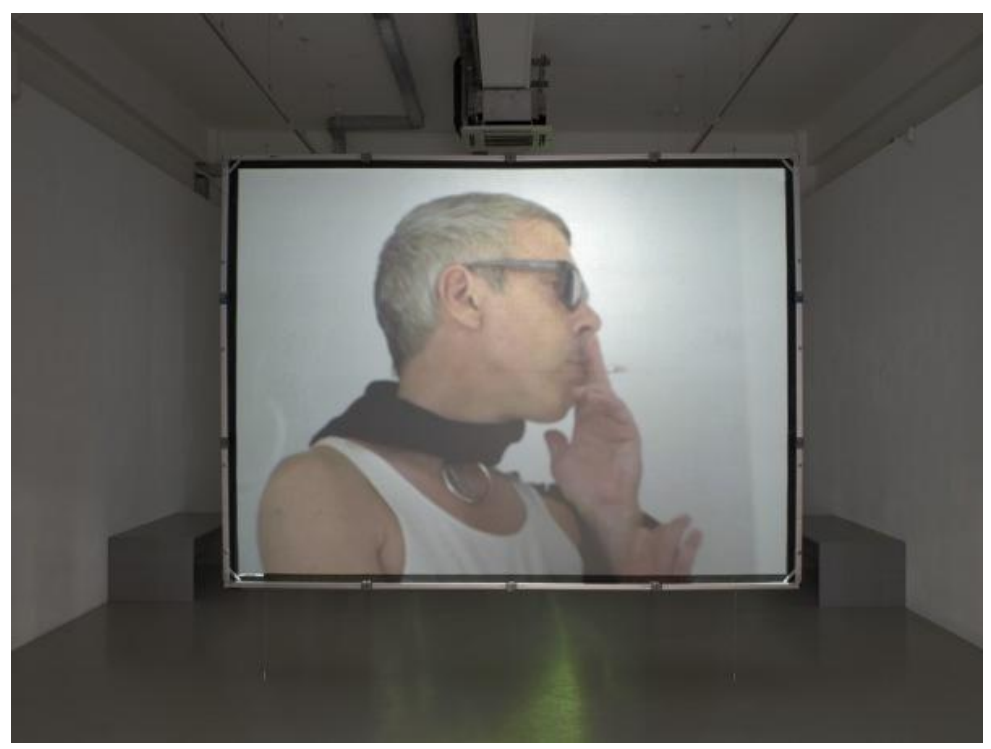

Resim 4.Tate Müzesi içinde gösterilen 2013 yapımı Rirkrit Tiravanija, 2012 (Karl'ın mükemmel günü için bir çalışma) ya da (eşsiz Karl Holmqvist)

Pierre Huyghe ise inşaat işçilerini fotoğraflayarak bu alana bakan bir panoda bu fotoğrafları sergiler, böylelikle yapılan işin görünürlüğü kendi dili ile dolaşıma sokulur.

Liam Gilick ve Carl Andre'nin benzerlikleri olan bölgelerin temsillerine odaklandığını bu süreçte konuşmanın, tartışmanın, müzakere etmek ve dahası bunun gibi eylemler içinde sanatın düşünüldüğünü görürüz. Sanatçıların çalışmalarında birey ve toplum arasındaki fiziksel ve ideolojik sınırların tespiti önem taşımaktadır. Toplumla temas eden şeylerin belli alışkanlıklar ile biçimlenerek eylemsizlikten kurtulduğu gözlenir. Bourriaud "Sanat işlevsel evrenin içine süzülüvererek bu nesneleri diriltir ya da anlamsızlıklarını açığa vurur" der (Bourriaud, 2004, s. 117). Postprodüksiyonda sanat işinin tekrar ve tekrar üretilmesi ve üzerine düşünülmesi sonrası sanat neye dönüşmektedir? Bu biçimde yeniden tanımlanan çalışma edimi, boş zamanda sınırların kaybolmasına neden olacaktır. Profesyonel bir çalışma hayatında ev ve ofis ayrımı yapılmıyor çünkü hızlı ulaşılabilir ve daima çalışmaya uygun çalışanlar çalışma hayatının yeni profilini oluşturmaktadır. 


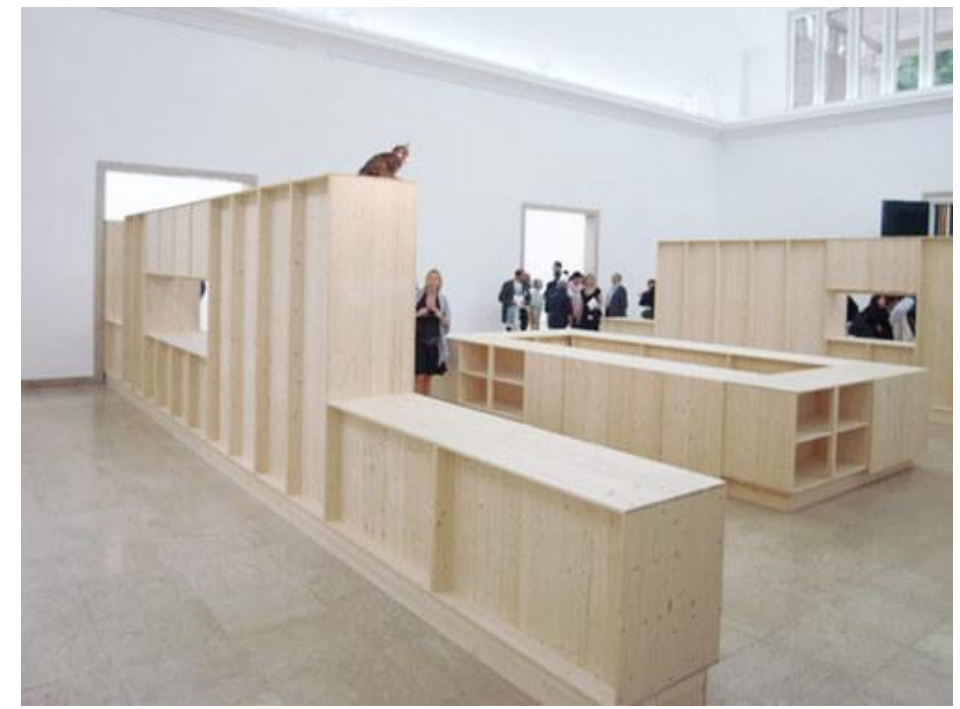

Resim 5. Liam Gillick'in Venedik Sanat Bienali'ndeki Alman Pavyonu ana odasinda, 'Mutfak', 2009

Bellek yaratmada zamanın etkileri düşünüldüğünde toplumda yaşanan gelişme ve yeniliklerin insanın yakın çevresi daima belirleyici olmuştur. Altmışların sanatından günümüz sanatına toplum yaşantısı ile sanat arasındaki bağın sanatsal işlere yansıdı̆̆ gözlenir. Dönemin baskın malzemesi olarak görülen üretim elemanlarının gündelik yaşantı ile olan ilişkileri önem arz eder. Minimalist heykelde alüminyum, çelik ve neon gibi malzemelerden yapılması ile dönemin hâkim imalat unsurlarının sanatta da karşıllı̆ını bulur. Pop sanatının eşleştiği alan ise gündelik hayatta süpermarket ve alışveriş merkezlerinde fetişleşen tüketim mallarıdır.

Micheal Wilson zaman boyutu ile sanat ilişkisini açıklarken yaşanan kısa süreli dönüşümlerin yol açtığ1 dönüşümleri önemli değişimlerin küçük adımları olarak belirtir. Günümüzde hayatın içinde yer bulan pek çok gündelik tanımlanın bağlamla birlikte dönüştüğü gözlenmektedir (Wilson, 2015, s. 6). Kavramsal sanatın düşünsel boyutu ise hizmet sektörünün yükselişine bağlanabilir. Sanat bu yönlü kullanımı ile sonsuz alternatifler üreterek dünyayı yeniden bir sosyal paylaşım alanı olarak tahayyül edebilmemizin imkanını sağlamaktadır.

\section{Müze Bellek İlişkisinin Seyri}

Müzelerin sanatsal bellek birikiminde toplumsal bir yapı olarak temsil ettiği konum son derece önemlidir. Andreas Huyssen, modern biçimi ile ilk olarak Fransız Devrimi zamanında ortaya çıkan müze olduğunu belirtir. Louvre'un bugünkü işlevini sağlayan dayanağın Fransız Devrimi'nin içinde yattı̆̆ bir gerçektir. Huyssen, "İlerleme firtınasının payandası olmuş, gelenek ile ulusun, tarihsel miras ile kanonun eklemlenmesinde bir katalizör işlevi görmüş ve gerek ulusal gerek evrenselci anlamda kültürel meşruluğun kuruluşunun ana planlarını sağlamıştır" diyerek ilk müzelerin toplumsal bellekteki önemini ortaya koyar (Huyssen, 2012, s. 259).

Özellikle kamuya açık halde toplumsal ilişkiler bütünüyle kurulan bir müzenin ziyaretçisinin eserleri ile kendine hayran bırakan ilişkisi bu eserlerin sahipleri ile toplum arasındaki düzeni hatırlatır. Buraya gelen kişileri karşılayan eserler tek tek beğenilere sunulmuş birer güzellik nesnesi olmanın ötesinde, hükümdar ya da devletin gücünü ziyaretçiye hissettiren mabet görevi görüyordu. Buna yönelik Carol Duncan ve Alan Duncan'ın müzelerin işlevleri üzerine iddialı fikirler ortaya koyar. İkili Galerinin görsel temsili yetisinin içerik ve sunduğu akışın büyüklüğü ile meşrulaştırma işlevi gördüğünü aktarır. Müzede, koleksiyonun zenginliği toplumsal birikimin bir göstergesi ve belleğin inşasının temel merkezi olarak vazife gördüğü belirtilir (Duncan \& Wallach, 2012, s. 64). Müzedeki belleğin gelenleri etkisi altına almayı amaçladığı kesindir. Günümüzde toplumsal bellek ile müze ilişkisinde güçlü ve zengin sahibin yerini iktidar almıştır ziyaretçiyi etkilemeyi amaçlar. 
Müzenin geçmiş işlevlerinde önemle yer alan ulusallık ideali yaratma hedefi tebaaya bağlanma ve aidiyet temelli düşüncenin ürünüdür. Bu önemi fark eden kıta Avrupa'sındaki devletler Fransız Devrimi sonrası kendi ulus müzelerinin kurulmasına çaba göstermişlerdir.

Müzelerdeki belleğin inşasına yönelik yerleşik beklentilerin, günümüz koşullarında yeniden kurgulandığı gözlenir. Bu kurgulama da zamanın klasik tapınakları olmaktan çıkan bir mabet olan müze, halkın kullanımına açılarak bir gösteri mekânı hatta alışveriş merkezlerine dahi benzetilmektedir. Sosyolojik bakımdan değişen müzenin konumunun tartışıla geldiği günümüz koşullarında bellek oluşumuna ilişkin beklentilerin daha sosyal ve kapsamlı bir beklenti ile oluşturulması gereklidir. Klasik tanımlamadaki hedefleri post modern süreçte hayli eleştirilen müzelerin varlığına yönelik beklentiler geleneğin dışa alınarak kültürün inşasında müzeyi hedef tahtasına koymuştur. Özellikle müzelerin tümden kapatılmasının dahi istendiği bu karşı ütopyanın gerçekleşmesi olası görünmese de yine de yapısal bazı dönüşümlerin başlamasına neden olmuştur. Özellikle Huyssen sanatın yaşama katılımı ile ilgili avangardist düşüncenin müzeleşmesindeki çelişkiden yola çıkarak müzelerin az da olsa dönüşüme uğradığını belirtir. Müzelerin "En azından ulaşılabilirlik açısından demokratikleşmesine ve seçkin azınlığın kalesi olmaktan bir kitle iletişim aracı olmaya, kutsal nesneler hazinesi olmaktan daha geniş bir halk kitlesi için bir gösteri alanı ve bir mizansen olmaya doğru son zamanlarda geçirdiği dönüşme" çabasına önem vermektedir (Huyssen, 2012, s. 270).

Linda Nochlin de benzer bir dönüşüm ihtiyacını toplumsal beklentiler üzerinden dillendirir. Nohlin tuval resminin belirli oranda terk edilmesi ile birlikte bir heyecan ve kırılmanın yaşandığını belirtirken; bilindik söylevlerin "sanatın ölümü”, kültürün ortadan kaldırılması" ve "müzelerin sonu" gibi yıkıcı söylevlerin karşılığının sorgulanmasına değinir. Fakat kültürel bellek oluşumunda bu derece aykırı söylevlerin arasında onca yaşanan kitlık, savaş ve göç gibi evrensel sorunların arasında müzelerin hangi belleğin üzerine içeriklerini oluşturduklarını sorgulamaktadır (Nochlin, 2012, s. 43).

Cleas Oldenburg 1960'larda gündem yaratan çıkışı ile dikkatleri üzerine çekmiştir. Oldenburg "Ben, müzede kıçının üzerine oturmaktan başka bir şey yapan bir sanattan yanayım" derken sanat eserlerinin vitrinde sergilenen birer metaya dönüşmesine yönelik tepkisini ortaya koyuyordu (Grunenberg, 2012, s. 98). Bu sözleri ile müzelerin yaşamla olan bağını gündelik ilişkiler temelinde sorgularken bellek ve yeniden tanımlanan müzelerin ürettiği içeriğin anlamını eleştirmiştir.

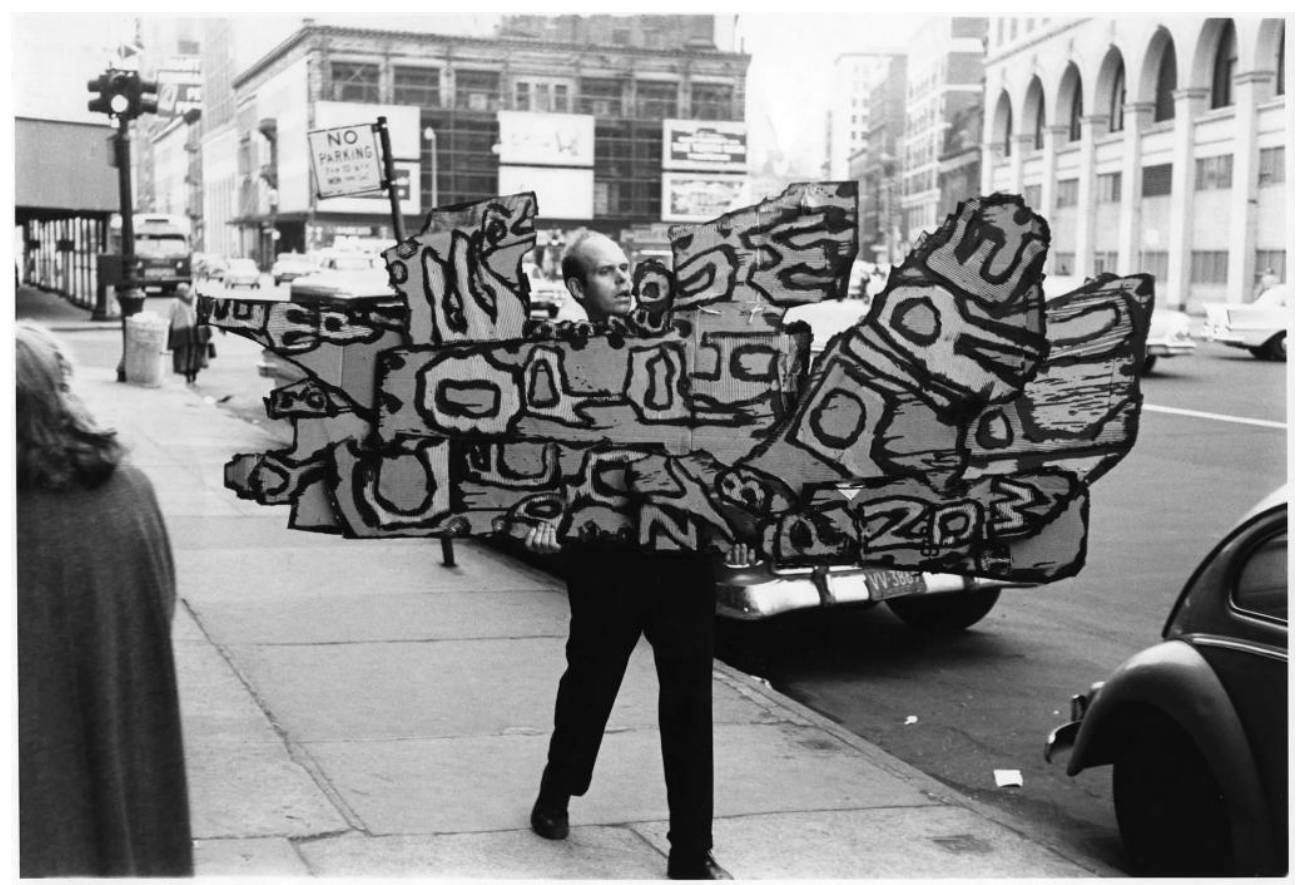

Resim 6. "Sokak Tabelasını" taşıyan Claes Oldenburg (1960) Reuben Gallery, New York 
Müze ve kültürün ürettiği belleğe yönelik eleştirilerin en önemlilerinden biri de Adorno tarafindan dile getirilir. Theodor Adorno Kültür Endüstrisinde bellek oluşumundaki bu aykırı duruşunu seri üretim sanayi mallarının değerlerindeki ucuzlama ile genişleyen ticari ağları değil sanatın gündelik değerini kendi iç değeri ile bu pazarda yer bulması üzerinden aktarmaktadır (Adorno, 2014, s. 94-95). Sanat ve kültür üretiminde dönemin koşullarını dikkate alan görüşlerde belleğin oluşumuna ilişkin değerlendirmeler de önem kazanır. Ahu Antmen ise endüstriyel gelişme ve sanayileşme hareketleri ile toplumdaki dönüşümün sanatta karşılık bulduğunu aktarır. Ancak bu dönüşüm aynı zamanda hayatın kolaylaşmasını sağlasa da toplumsal duyarlılığın terk edilmesi ile yan etkiler doğurduğunu aktarmaktadır (Antmen, 2013, s. 18). Sanatın günümüz koşullarında kurgu olanakları ile yeniden düşünüldüğü gözlenmektedir. Post prodüksiyon yani üretim sonrasını düşünmek ve belleğin bu dönüşümdeki yeri sanatla ilişkili bir geleceğin toplumla ilişkisi temelinde ele alınmaktadır.

\section{SONUÇ}

Sanatın bellek ile ilişkisi düşünüldüğünde yalnızca üretim sürecinin önemsenmesi günümüz etkileşim çağında pek olası değildir. Günümüz toplumu kısalan mesafeler ve teknolojinin sağladığı kolaylıklar ile pek çok şeyde olduğu gibi sanatsal bellek oluşumunda da ilişkilerin doğurduğu sonuçları önceden hesaba katmalıdır. Sanat ve sosyallik ilişkisi yapıtın üretimi sonrasında sürekli yeniliğe açık bir halde kurgulanmalıdır. Bellek oluşumunun toplumsal karşılığı düşünüldügünde mevcut unsurların yalnızca üretildiği an ile sınırlanması yapıtın olası gelişimini kısıtlayacaktır. Bu doğrultuda sanat günümüz koşullarında daha çok hayatla şekillenen, dönüşen bir halde üretilmektedir. Sanatçılar günümüz post modern yaşam şartlarında sosyal alanda kendiliğinden gelişen deneysel çalışmalar üzerine düşünmelidir.

Müzelerin sanat ve hayat buluşmasında önemi ortadadır. Günümüz müzelerinin bir dönüşüm geçirerek geçmiş amaçlarından farklı bir çizgide kurgulandığı gözlenmektedir. Günümüz müzeleri yaşam ile daha dolaysız bağlantı kurabilen bir yapıda yaşamın kendisi gibi esnek ve değişken bir yapıda kurgulanmalıdır. Aynı biçimde sanat eserlerinin de sunulacağı mekânda ilişkiler üretmeye yönelik kurgulanması önemlidir.

$\mathrm{Bu}$ doğrultuda bellek ve sanat ilişkisi zamanın ve yaşamın gerçek amaçları ile bağ kurabilen değişime ve dönüşüme açık hale gelecektir. Sanatın toplumla olan bağının ortaya koyduğu amaçları dışında toplumla değişebilen bir yapıya dönüşmesi bu bağlamda önemlidir. Sanat eserinin yapımı sonrasını düşünmek gelecekte olası pek çok ihtimali değerlendirmeye almayı gerektirmektedir. Bu belirsizlik, sanat eserinin bitmiş̧liğini değiştirirken toplumsal bellek ile her dönemde yeniden kurgulanmasının da önünü açacaktır.

Bu çalışmada da üzerinde durulduğu gibi sanat eseri için maddi değer ve eder üzerinden gerçekleşen bir başarı değerlendirilmesinin günümüz başarılı olma beklentilerini ne derece uyacağı da sorgulanmalıdır. Önümüzdeki sonbaharda gerçekleşmesi beklenen İstanbul Bienali'nde ise bu durumun bir tezahürü ile karşılaşmamız olasıdır. Yaşayan belleklerle gerçek anlamını bulan çalışmaların bu anlamda gerçekleşecek bu etkinlikte gündemde olacağı da beklenmelidir. Bu beklentilerin önümüzdeki dönemde ülkemiz sanatı için bakılırsa değişime açık, kolektif bir argümana hazırlanılmasının önemini ortaya koymaktadır. Geçmiş dönem gerçkeleşen çalışmaların da etkileri hesaba katıldığında toplum sanat birlikteliğinin bellek ile şekilleneceği en azından bienalin yapısını oluşturması muhtemeldir.

Bilgilendirme / Acknowledgement: Bu çalışma Haziran 2019 tarihinde İstanbul'da gerçekleşen 2. Uluslararası Eğitim ve Sosyal Bilimlerde Yeni Ufuklar Kongresi (ICES-2019) adlı kongrede sözlü bildiri olarak sunulmuştur.

\section{KAYNAKÇA}

Adorno, T. W. (2014). Kültür endüstrisi kültür yönetimi. T. Adorno içinde Kültür Endüstrisi (s. 45150). İstanbul: İletişim Yayınları.

Akay, A. (2004). Önsöz. N. Bourriaud içinde Postprodüksiyon (s. 7-12). İstanbul: Bağlam Yayıncılık. Antmen, A. (2013). 20. Yüzyılda Batı sanatında akımlar. İstanbul: Sel Yayıncılık.

Başar, M. R. (2015). Yeni sanatçı, yeni izleyici, yeni sanat teknolojileri ve çağdaş sanat eğitimi. Aydın Sanat, (2), 103-106. 
Bourriaud, N. (2004). Postprodüksiyon. (Çev.A. Akay, Dü., \& N. Saybaşl1). İstanbul: Bağlam Yayıncilik.

Bourriaud, N. (2005). İlişkisel estetik. (Çev. A. Akay, Dü., \& S. Özen). İstanbul: Bağlam Yayıncılık.

Çalıkoğlu, L. (2005). Çağdaş sanat konuşmaları (Cilt 1). İstanbul: Yapı Kredi Yayınları.

Debord, G. (1996). Gösteri toplumu ve yorumlar. (Çev. A. Ekmekçi, \& O. Taşkent). İstanbul: Ayrınt1 Yayınları.

Doğan, H. M. (1975). 100 soruda estetik. İstanbul: Gerçek Yayınevi.

Duncan, C., \& Wallach, A. (2012). Evrensel müze. A. Artun içinde, Sanat müzeleri 2, (s. 49-86). İstanbul: İletişim Yayıncılık.

Grunenberg, C. (2012). Modern sanat müzesi. A. Artun içinde, Sanat müzeleri 2 (s. 87-114). İstanbul: İletişim Yayınları.

Hinderliter, B., Kaizen, W., Maimon, V., Mansoor, J., \& McCormick, S. (2018, Haziran 11). Sanat ve cemaat: Çağdaş sanatta katılım ve kolektivite. 28 Temmuz 2019 tarihinde https://www.eskop.com/skopbulten/sanat-ve-cemaat-cagdas-sanatta-katilim-ve-kolektivite/3819 adresinden erişildi.

Huyssen, A. (2012). Bellek yitiminden kaçış: Kitle iletişim aracı olarak müze. A. Artun içinde, Sanat müzeleri 2, (s. 259-277). İstanbul: İletişim Yayınları.

Nochlin, L. (2012). Müzeler ve radikaller: Bir olağanüstü durumlar tarihi. A. Artun içinde, Sanat müzeleri 2, (s. 11-48). İstanbul: İletişim Yayınları.

Rajchman, J. (2013). Çağdaş: Yeni bir fikir mi? A. Artun, \& N. Özge içinde, Çağdaş sanat nedir? (Çev. Ö. Çelik, E. Gen, S. Kılıç, K. İz, A. H. Köksal, Z. Baransel, \& N. Özge, s. 19-35). İstanbul: İletişim Yayınları.

Saybaşl1, N. (2004). Çevirmenin önsözü. N. Bourriaud içinde, Postprodüksiyon, (s. 13-19). İstanbul: Bağlam Yayıncılık.

Wilson, M. (2015). Çağgaş sanat nasıl okunur? (Çev. E. Koyunoğlu, Dü., \& F. C. Erdoğan). İstanbul: Hayalperest Yayınlar1.

\section{Resimler Kaynakçası}

Resim 1. 18 Haziran 2019 tarihinde https://www.mutualart.com/Artwork/TurkishJokes/3E78AA0D62E03E60 adresinden erişildi.

Resim 2. 18 Haziran 2019 tarihinde http://www.toutfait.com/on-the-creative-act/ adresinden erişildi.

Resim 3. 18 Haziran 2019 tarihinde https://suitcasemag.com/guides/paris/palais-de-tokyo/ adresinden erişildi.

Resim 4. 18 Haziran 2019 tarihinde https://www.tate.org.uk/whats-on/tate-modern/rirkrit-tiravanijaportraits/rirkrit-tiravanija-karl-holmqvist adresinden erişildi.

Resim 5. 18 Haziran 2019 tarihinde http://www.metamute.org/editorial/articles/being-liam-gillick adresinden erişildi.

Resim 6. 18 Haziran 2019 tarihinde https://walkerart.org/magazine/claes-oldenburg-i-am-for-an-art1961 adresinden erişildi. 